\title{
Baileo as a peace model for Christian and Muslim communities in Maluku
}

\begin{tabular}{|c|c|}
\hline \multicolumn{2}{|c|}{$\begin{array}{l}\text { Authors: } \\
\text { Resa Dandirwalu } \\
\text { Husnul Qodim² }\end{array}$} \\
\hline \multicolumn{2}{|c|}{$\begin{array}{l}\text { Affiliations: } \\
{ }^{1} \text { Department of Theology, } \\
\text { Faculty of Theology, } \\
\text { Universitas Kristen Indonesia } \\
\text { Maluku, Ambon, Indonesia }\end{array}$} \\
\hline \multicolumn{2}{|c|}{$\begin{array}{l}{ }^{2} \text { Department of Theology, } \\
\text { Faculty of Theology, UIN } \\
\text { Sunan Gunung Djati } \\
\text { University, Bandung, } \\
\text { Indonesia }\end{array}$} \\
\hline \multicolumn{2}{|c|}{$\begin{array}{l}\text { Corresponding author: } \\
\text { Resa Dandirwalu, } \\
\text { resadandirwalu@gmail.com }\end{array}$} \\
\hline \multicolumn{2}{|c|}{$\begin{array}{l}\text { Received: } 09 \text { Feb. } 2021 \\
\text { Accepted: } 22 \text { Apr. } 2021 \\
\text { Published: } 29 \text { June } 2021\end{array}$} \\
\hline \multicolumn{2}{|c|}{$\begin{array}{l}\text { How to cite this article: } \\
\text { Dandirwalu, R. \& Qodim, H., } \\
\text { 2021, 'Baileo as a peace } \\
\text { model for Christian and } \\
\text { Muslim communities in } \\
\text { Maluku', HTS Teologiese } \\
\text { Studies/Theological Studies } \\
\text { 77(3), a6529. https://doi. } \\
\text { org/10.4102/hts.v77i3.6529 }\end{array}$} \\
\hline \multicolumn{2}{|c|}{$\begin{array}{l}\text { Copyright: } \\
\text { (C) 2021. The Authors. } \\
\text { Licensee: AOSIS. This work } \\
\text { is licensed under the } \\
\text { Creative Commons } \\
\text { Attribution License. }\end{array}$} \\
\hline \multicolumn{2}{|l|}{ Read online: } \\
\hline 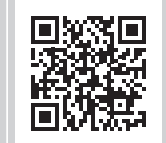 & $\begin{array}{l}\text { Scan this QR } \\
\text { code with your } \\
\text { smart phone or } \\
\text { mobile device } \\
\text { to read online. }\end{array}$ \\
\hline
\end{tabular}

This article aims at analysing Baileo as a peace model for Christian and Muslim communities from the gandong countries in Maluku. The countries include Hutumuri (Christian), Christian Sirisori, Islamic Sirisori and Tamilou (Islam). Baileo as a peace model was lost during the 1999 social conflict in Maluku. Baileo (bale) is a place to discuss problems and a place for implementation of customary rituals in the country, whilst gandong is a relationship between two or more countries based on blood or hereditary relations. The approaches used are cultural anthropology and functional theology. This research study uses a qualitative research method with observation and interview techniques for data collection and Appreciative Inquiry (AI) model for data analysis. As shown in the Results and Discussion section, firstly, Baileo is a place to create solidarity between Christian and Muslim communities because of the gandong ties between them, which were very good before the conflict; secondly, the local traditions of Baileo and gandong have become a meeting point for Christian and Muslim communities because Baileo has sacred values, and gandong has mutual care and protection values as an implementation of ancestral promise; thirdly, reviving the fraternal solidarity of Christian and Muslim communities based on collective memory through shared awareness, cultural romanticism and retelling; and fourthly, the implementation of the traditional ritual of the inauguration of Raja Hutumuri in Baileo as a manifestation of peace for Christian and Muslim communities in Maluku because of the absence of mutual suspicion and equality between Christianity and Muslims.

Contribution: The contribution of this study is that local culture, in this case Baileo, is very relevant for solutions or a common ground for resolving socio-religious conflicts at local, national and global levels. Thus, it needs to be developed continuously.

Keywords: Baileo; Gandong; cultural anthropology and functional theology; solidarity; harmony.

\section{Introduction}

Indonesia is known to be a tolerant country in the world because of its ability to unite various religions, such as Christianity, Catholicism, Islam, Hinduism, Buddhism and Confucianism. According to Asadu, Diara and Asogwa, religious diversity adheres to the belief that every religion has the same good values (Asadu, Diara \& Asogwa 2020:1). Meanwhile, according to Min Kim, Banawiratma and Sofjan (2020:160), Indonesia has a unique history of interfaith relations, and its strength lies in the local values of the Indonesian people because Indonesia also has ethnic diversity, such as Central Kalimantan, Sumba (Suparlan 2014:24), Javanese, Sundanese, Mauda, Dayak, Acek, Flores, Papua and Ambon. According to Roswantoro (2016:187) the tolerance created enables people to be more mature in living together with other religious people. In contrast, according to Parihala and Busro (2020:1), the negative value is that Indonesia is very vulnerable to conflicts with religious nuances or in other words, conflicts can occur throughout history wherever and whenever (Oppenshaw, Nel \& Louw 2018:1). Regarding the conflict, Min Kim, Banawiratma and Sofjan (2020:161) noted that there are religious conflicts that affect social relations in several regions of Indonesia, such as Maluku, Poso and Java. One of the causes is territorial segregation based on religion as reported in Maluku. It means a Muslim community resides in areas or territories that are predominantly Muslim, and vice versa; Christian communities reside in areas or territories that are predominantly Christian (Dandirwalu 2014:39). Even so, Indonesia has a strong social and cultural capital, namely, Pancasila, therefore the conflict can be reduced (Amir 2013:54). Moreover, based on historical records, Pancasila is the unifier of various religions and ethnicities in Indonesia (Pattipeilohy 2018:123) because it has universal

Note: Special Indonesian Collection: Philosophy, Culture and Theology, sub-edited by Busro Busro (Sunan Gunung Djati State Islamic University of Bandung). 
values based on every religion and ethnicity in Indonesia. It indicates that social and cultural forces are used as a model for creating a brotherly life between different religions and ethnicities in Indonesia.

This article is based on the social conflict in Maluku in January 1999. Before the conflict, there were traditional rituals in Baileo, which involved Christian and Muslim communities. As time passed, it disappeared in several countries that have gandong ties, such as Hutumuri (Christian), Sirisori (Christian), Sirisori (Islam) and Tamilouw (Islam) in Central Maluku Regency. All parties try to construct peace in these countries but it has not yet come to fruition as there was still conflict in the years 2004, 2011 and 2012 in Maluku (Dandirwalu 2014:43). The question is how can Christian and Muslim communities from Hutumuri (Christian), Sirisori (Christian), Sirisori (Islam) and Tamilouw (Islam) countries create peace? Baileo became a peace model for them. Baileo is an important traditional symbol in Maluku. The word Baileo derives from the Maluku language bale. It is rooted in Malay. Bale is a place to discuss problems in the country and a place for traditional rituals to be performed (Cooley 1987:113). Baileo has other meanings such as the old country house and the clan heirloom house because the community uses it as a place to store heirlooms related to ancestors. The shape of the building Baileo is a rectangle, with no windows, walls and doors because the ancestors are free to go in and out of Baileo. Four pillars support the building. The height is 2 metres because the ancestors were taller than humans. Beside it is a taboo stone (pamali) about 2 metres in size (Cooley 1987:114-115).

The existence of ancestors in Baileo, both among Christian and Muslim customary communities, makes it a sacred symbol. Thus, the treatment of Baileo cannot be arbitrary because they believe that ancestors will punish them. For example, those being present at Baileo must wear traditional clothes, without shoes and a muzzle, at certain time and on certain days.

Many experts have researched the study of peace. Some of them focused on the study of scripture; Parihala and Busro reinterpreted the Bible texts so that they can serve as a meeting point amongst religions to create peace using the interpretive approach of Luke 12:49-53 (Parihala \& Busro 2020).

Many scholars also analysed the peace of a certain country. Asadu, Diara and Asogwa examined religious conflicts in Nigeria. According to them, Nigerians can create peace by recognising the existence of diversity amongst them. It is the panacea for them (Asadu et al. 2020).

Some investigated peace in a certain province and district of Indonesia. Faisal et al. (2019) researched the model of living together amongst Muslim immigrants in Papua by strengthening the economy, politics and communication (Faisal et al. 2019); Lestari (2020) examined music as a model in creating peace among conflicting communities in Maluku with the musical approaches Hadroh and Trompet; Dandirwalu (2014) examined the reality of post-conflict segregation using a social anthropological approach. The peace in Ambon can be realised through the ambon manise totem (Dandirwalu 2014); Dandirwalu and Rehy (2020) analysed tahuri as a symbol of peace for Christian and Muslim communities in Tehoru and Telutih using a symbolic anthropological approach. It has collective values and cohesion for society; Iwamony (2019) analysed the openness of the Gereja Protestan Maluku (GPM) congregation towards Islam. The open attitude can create peace between the GPM and Islam in Maluku.

Based on the above description, there are no previous studies where experts focus on the Baileo based on Cultural Anthropology and Functional Theology approaches. Thus, the authors regard that this study can provide a new alternative for creating inter-religious peace in Maluku and Indonesia. The new alternative is Baileo become a model of peace as a symbol of solutions or meeting points in the resolution of socio-religious conflicts (in the name of religion) either in Maluku or in Indonesia.

\section{Conceptual review of cultural anthropology and functional theology}

In this section, the authors explain how the conceptual review analyses field data based on cultural anthropology and functional theology approaches, and answers the problems being studied in this article.

\section{Cultural anthropology}

According to Eriksen (2017:7) anthropology means talking about understanding culture, society and humanity through a systematic study of the lives of local communities, thus showing that the world is richer and more complex than assumed. Anthropology offers two kinds of insights. Firstly, anthropology produces knowledge about the actual cultural variations in the world, such as the study of the roles of caste and wealth, religions, customs, kinship and gender. Secondly, anthropology offers methods and perspectives that allow practitioners to explore, compare and understand various expressions of human existence (Eriksen 2017:7). According to Kottak (2015), anthropology is a field that studies humans and ancestors. The study is comparative and holistic because it talks about the whole human condition: past, present and future; biology, society, language and culture. Thus, anthropology is a humanistic science that seeks to discover and explain the similarities and differences in space and time amongst humans and their ancestors; understand and appreciate it (Kottak 2015:2). Kluckhohn (1985:11) described anthropology as a field that studies and provides a basis for research on human similarities and differences related to appearance, language and way of life. Thus, anthropology is often referred to as a panacea for all human diseases. 
Cultural anthropology is one of the fields of anthropology which focuses on the past and present societies, as well as on the dynamics that take place in social life and customs (Kottak 2015:6). Thus, cultural anthropology is the study of society, humans and culture. It is involved in two activities: ethnography and ethnology (Kottak 2015:7). According to Birx (2006:613), cultural anthropology is often referred to as cross-cultural research, which usually uses field data and previously collected data for analysis.

\section{Functional theology}

Functional theology is the theology that was developed by Banawiratma, which shows a real theological effort that is rooted in human experience and the experience of faith (rooted in contextual experience) to help the living of faith (Banawiratma 1988:51-53). There are three reasons for functionalisation (alternatively inculturation or contextualisation): firstly, the Living of Christian Faith based on the Gospel of Jesus Christ always occurs in certain concrete situations, environments, contexts or cultural systems. This concept is in line with the thought of Bevans (2002) related to the anthropological model, which focuses on the values and goodness of the Anthropos and the human person. According to him, in every person, society, social location and culture, God reveals his divine presence. Thus, the theologian is not merely a matter of relating a proclamation from the outside, that is, the manifestation that takes place is always contextual, namely: starting from the present context of a particular society and culture (Bevans 2002). Secondly, the concrete context or the concrete cultural order is not only the 'object' that the gospel calls out but the active 'subject'. This concept is what Singgih (2016) mentioned as an attempt to find one's self-worth as a Christian in the context of its existence, namely, local culture. Meanwhile, Schreiter (1985:22) stated that three pillars interact dynamically and dialectically throughout history - gospel, church and culture. Thirdly, being faithful means being called as a new creation in the real-life situation in the church or in other words, the constant struggle to be where Jesus Christ is.

This study aims to analyse Baileo as a model of peace for Christian and Muslim communities from Gandong countries: Hutumuri (Christian), Sirisori (Christian), Sirisori (Islam) and Tamilouw (Islam), based on cultural anthropology and functional theology approaches.

\section{Research method}

This field research study used a qualitative research method because this method can reveal the social problems of humanity of a particular individual or group (Creswell \& Creswell 2018:43). It has five characteristics: (1) studying the meaning of a society's life in its world, (2) representing the thinking of the community, (3) contextual conditions of a society, (4) the emergence of various thoughts to explain the social behaviour of a society, and (5) using a variety of sources (Robert 2011:7-8).
To collect field data, the authors conducted in-depth observations and interviews from April to June 2020 with several informants who were credible in providing information, namely, kings, traditional leaders, religious leaders and community leaders of Hutumuri (Christian), Sirisori (Christian), Sirisori (Islam) and Tamilou (Islam). The four countries have a very strong tie to gandong culture; however, when the conflicts appear, all ties are severed. The data analysis is based on the cultural anthropology and functional theology approaches with an Appreciative Inquiry (hereinafter abbreviated to AI) model. It means that each stage of the AI model contained the values of cultural anthropology and functional theology.

The AI model has several concepts. Firstly, it appreciates the told human experience (Whitney \& Trosten-Bloom 2014:47) to seek, identify and increase the 'life-giving power' that is present when the system works optimally in human life (Waltkins, Mohr \& Kelly 2011:22). Secondly, it has a cycle known as four-dimensional (4D) stages: Discovery, Dream, Design and Destiny (Cooperrider, Whitney \& Stavros 2005:xv). At the Discovery phase, the authors analyse data related to the best experience of all stakeholders. At the Dream stage, the authors analyse data relating to opportunities or the best vision of the strengths in the future. At the Design phase, the authors analyse data relating to the embodiment of the experience and the best opportunities. At the Destiny stage, the authors analyse data related to efforts to create a social order that allows the involvement of all parties for a change (Cooperrider et al. 2005:16).

\section{Result and discussion}

In this section, the authors discuss the $\mathrm{AI}$ model with $4 \mathrm{D}$ stages: (1) Discovery is the best experience that has existed from all stakeholders; (2) Dream is the best opportunities/ visions that become the strength of the future; (3) Design is the embodiment of the best experiences and opportunities; and (4) Destiny creates a social order that allows the involvement of all parties for a change. Thus, the selection of AI models is supported by several factors. Firstly, the AI model greatly emphasises and appreciates the human experience. Secondly, the AI model is based on the power it has ('life-giving power'), which is present when the system works optimally in human life.

\section{Discovery stage: Baileo as a place to create solidarity between Christian and Muslim communities}

At the Discovery stage, the authors analyse the experiences of both Christian and Muslim communities towards Baileo before the 1999 social conflict in Maluku. To hear their stories, the authors interviewed the kings of Hutumuri, Christian Sirisori, Islamic Sirisori, and Tamilou. They stated:

'Before the conflict, Baileo is always a place for us to gather.' (King of Hutumuri, 52 years old, private)

'... and discuss various happening problems as our agreement.' (King of Christian Sirisori, 53 years old, self-employed) 
'Besides, we always carry out traditional rituals in Baileo and it will not start if one of the countries is not present.' (King of Tamilou, 57 years old, retired state civil servant)

'Because of the conflict, we cannot do it anymore.' (King of Islamic Sirisori, 59 years old, self-employed)

Traditional leaders of these four countries also stated the same. Moreover, they call their countries as sibling countries. They stated:

'In every traditional event, we as sibling countries gather in Baileo to carry out traditional activities.' (Traditional leaders from Christian Sirisori [65 years old, farmer] and Hutumuri [68 years old, farmer])

'But, since the conflict happened in Maluku, we cannot do it anymore because we are afraid of being killed.' (Traditional leaders from Islamic Sirisori [68 years old, farmer] and Tamilou [69 years old, farmer])

Furthermore, both Christian and Muslim religious leaders from Hutumuri, Christian Sirisori, Islamic Sirisori and Tamilou admitted that they live in harmony before the conflict:

'We are very happy in every traditional event together.' (Religious leader from Islamic Sirisori, 61 years old, ulama)

'... because through this event the sibling countries such as Hutumuri, Christian Sirisori, Islamic Sirisori, and Tamilou always come together.' (Religious leader from Tamilou, 63 years old, ulama)

'The atmosphere is very harmonious.' (Religious leader from Christian Sirisori, 45 years old, pastor)

'But during the conflict, we cannot find its atmosphere anymore.' (Religious leader from Hutumuri, 51 years old, pastor)

Then, the community leaders of the four countries stress as follows:

'All traditional events from Hutumuri, Christian Sirisori, Islamic Sirisori, and Tamilou become events which we mingle with one another in the peaceful atmosphere as brothers and sisters.' (Community leaders from Tamilou [59 years old, farmer] and Islamic Sirisori [61 years old, farmer])

'But we cannot feel that atmosphere because of the conflict in Maluku.' (Community leaders from Hutumuri [58 years old, state civil servant] and Christian Sirisori [59 years old, farmer])

Based on the data above, it is evident that Baileo holds significant value as a place to create solidarity between Christian and Muslim communities. The existence of ties as siblings (gandong) influences the solidarity between them. Thus, they have the same interest, namely, harmony. Dean (1995:115) called it affection solidarity, which means the solidarity created based on certain relationships (love and friendship) to have emotional experiences and feelings of mutual care and concern. Moody and Achenbaum (2014:152) named it a community of interests and recognition of common interests. According to Alfaqi (2015:113) solidarity is created because of an agreement from individuals or groups to achieve certain goals. Harmony has implications in their daily lives in three ways. Firstly, there is an order amongst them to avoid internal conflict; secondly, if there is a problem amongst them, they always discuss and resolve it together in Baileo; thirdly, if the community members are traveling and crossing one of the countries, they may take the harvest for consumption. According to Durkheim (1915:31) the bonds of solidarity among communities are very important to maintain a social order. Those who violate the order are said to have committed crimes so that the community is directly linked to the individual and society or community (Durkheim 1915).

The solidarity created between the Christian and Muslim communities continues to be preserved through traditional rituals in Baileo. These traditional rituals are the inauguration ritual of the king, the ritual custom of gandong and rituals of traditional weddings. According to Tarekegn and Terefe (2019:591), a ritual is a behaviour that depicts continuous socio-religious activities and follows the applicable rules. According to Bell (1992:15), a ritual becomes a model for a community to strengthen cohesion amongst them, whereas Morris (2003) states that a ritual politically functions as an integrative and social mechanism that restores group balance and solidarity because rituals are performed for preventing forces that are difficult to control (Segal 1997). Through customary rituals, the community represents a fundamental value, namely, a deep meaning of community history and loyalty to practice it in their daily activities. Additionally, Carter and Fuller (2016:16) say that through rituals, we can understand the collectivity of a community that is the symbolic interaction process. Symbolic interactions have three fundamental values: meaningful action, meaningful social interaction and meaningful interpretation (Rejeki Waluyajati \& Farida 2018:85). Thus, a process of symbolic interaction strengthens the cohesion and solidarity between Christian and Muslim communities because both communities always engage in social introspection and interpretation that is meaningful to them. It has a positive impact on the preservation of gandong (brother and sister) relationships.

The continuity of traditional rituals in Baileo depends heavily on the inclusive attitude of both Christian and Muslim communities. If they have mutual acceptance and respect for differences between them, they can continue traditional rituals in Baileo. It is in line with Normuslim's (2018:88) opinion that the essence of living together is mutual acceptance and with Casram's (2016:193) view that inclusion is an attitude that recognises the truth of other religions. Thus, they have a mutual respect for the teachings of other religions so that they live in harmony (Dandirwalu \& Rehy 2020). Nurcholish Madjid, a Muslim figure, has campaigned its idealism through his work: Harmonization among Islam, Indonesian, and Modernism, in which Zainal Abidin reviewed that Islam has an inclusive attitude because it has open and tolerant insights into anyone who comes and provides a suggestion. Islam is a religion for humanity in line with the teachings of Muhammad SAW (Abidin 2014:682). Even so, Casram added that the application of an inclusive attitude has two difficulties: firstly, the arrogance of each religion, or there is power domination from one religion to the others; 
secondly, accommodating various opposing attitudes and considering it as accepted truth (Casram 2016:194).

\section{Dream stage: Local traditions, Baileo and gandong become a meeting point for Christian and Muslim communities}

At the Dream stage, the authors analyse the best opportunities or visions that will become the strength of the peace of Christian and Muslim communities in the future. Based on the results of interviews with the Kings of Hutumuri, Christian Sirisori, Islamic Sirisori, and Tamilou, they stated:

'The lives of siblings should not be lost just because of conflict.' (King of Hutumuri [52 years old, private] and Tamilou [57 years old, retired state civil servant])

'Thus, through traditional rituals in Baileo, we are still trying to reconnect the lives of younger siblings which have been lost during the social conflict in 1999.' (King of Islamic Sirisori [59 years old, self-employed] and Christian Sirisori [53 years old, self-employed])

Traditional leaders of four countries conveyed a similar opinion during an interview that stated:

'We believe that we have to reconnect the lives of siblings which has been fractured.' (Traditional leaders from Hutumuri [68 years old, farmer] and Tamilou [69 years old, farmer])

'... because we still have Baileo which was not destroyed during the social conflict in 1999.' (Traditional leaders from Islamic Sirisori [68 years old, farmer] and Christian Sirisori [65 years old, farmer])

Furthermore, the authors collected the following data based on the interview with Christian and Muslim religious leaders from Hutumuri, Christian Sirisori, Islamic Sirisori and Tamilou:

'We must create the life of siblings as Christian and Muslim teachings.' (Religious leader from Tamilou, 63 years old, ulama)

'We believe Christian and Muslim communities can reunite ...' (Religious leader from Christian Sirisori, 45 years old, pastor)

'... because from a long time ago, sibling countries lived very intimately ...' (Religious leader from Hutumuri, 51 years old, pastor)

'... even though they had different religions and beliefs.' (Religious leader from Islamic Sirisori, 61 years old, ulama)

Then, the authors provide the following interview with community leaders from Hutumuri, Christian Sirisori, Islamic Sirisori and Tamilou:

'Sibling relations between Christian and Muslim countries are very good, so we are confident that we can create this relationship ...' (Community leaders from Tamilou [59 years old, farmer] and Islamic Sirisori [61 years old, farmer])

'... because we still have Baileo which can bring us together'. (Community leaders from Hutumuri [58 years old, state civil servant] and Christian Sirisori [59 years old, farmer])

Based on the results of the interview, it is illustrated that the local traditions of the community in the form of Baileo and gandong are still part of the lives of both Christian and
Muslim communities. It becomes their best opportunity or vision.

\section{Baileo as a sacred symbol}

The sacred symbol of Baileo makes it a binding force and a place of communication for both Christian and Muslim indigenous communities because they have a deep relationship with it. According to Eliade (1985:3) in primitive societies, symbols are always associated with religion, so that the cosmological structure and beliefs are expressed because it was created by the gods. The symbol also has a deep attachment or relationship with its owner so that it becomes a force to build a life for the community (Eliade 1985:5). Related to the sacred, Eliade (1957:20) shows that it occupies a heterogenous space because of the special rooms that are considered sacred such as when God said to Moses: '[ $t$ take off your shoes because the place where you are standing is a sacred place' (Ex 3:5). According to him, every sacred space indicates the existence of hierophany, namely, a sacred presence, and separates it from the profane environment, such as the story of Jacob's leader in Haran in Genesis 28:1219 (Eliade 1957).

Baileo as the binding strength between Christian and Muslim communities is expressed through various traditional rituals, such as the inauguration of the king, gandong relationships, and traditional marriages, which are continuously held there. Thus, Christian and Muslim communities have customary sentiments and persistent solidarity. According to Morris (2003:145-146), the symbolic expression of the community shows the awareness of individuals and communities for the continuity of social life among them because the ritual is the real form of expression to create the emotional condition. Then, it builds sentiment and solidarity amongst them (Morris 2003:145-146). Therefore, the sacred symbol of Baileo has a functional value as a meeting point for Christian and Muslim communities, as stated by Cassirer (1944:48), that the symbol is regarded as a designator and has a functional value because of its meaning. Symbols also have a historical function, so they have a deep relationship with these symbols (Musurillo 1957:357). Therefore, these symbols can facilitate the development of the personal and cultural characteristics of the community over time (LeRon Shults 2010:718). Thus, according to Bielo (2018), the ritual has important characteristics. Firstly, the ritual marks the relationship between the everyday world and the supernatural world; secondly, it has a communicative value; and thirdly, it reflects beliefs, moral values and commitments.

\section{Gandong}

Gandong means coming from one womb that has the same ancestor (Bakri 2015:55). According to Hehanussa (2009:4), gandong is defined as the existence of a relationship between two or more countries that share common ancestry. Dandirwalu (2014:35) explains that gandong is a social bond between Christian and Muslim countries because of their blood or hereditary relations, such as Hutumuri (Christian), Sirisori (Christian), Sirisori (Islam) and Tamilou (Islam). 
Historically, the formation of gandong amongst these countries, the authors interviewed traditional leaders from Hutumuri, Christian Sirisori, Islamic Sirisori and Tamilou as follows:

'In the 16th century, there were two people namely husband and wife. Living on a rock in the land of Hatumeten. They have three sons and two daughters. The first child was named Temanolle, the second was named Simanolle, the third was named Silaloi, the fourth was named Nyai Intan, and the fifth was named Nyai Mas.' (Traditional leader from Hutumuri, 68 years old, farmer)

'Because of the war in Hote-Banggoi, the three boys took part in it, but they chose to help the Portuguese against the people from Hote-Banggoi. After they won, they separated.' (Traditional leader from Tamilou, 69 years old, farmer)

'Before parting on the boat, the three of them tied the little finger of the left hand with a thousand leaf bones (Achillea millefolium) and cut the tips of the fingers.' (Traditional leader from Islamic Sirisori, 68 years old, farmer)

'Then they drank the blood swearing: "One must not forget or overpower the other. Those who oppose this agreement are cursed by the ancestors to their children and grandchildren".' (Traditional leaders from Christian Sirisori, 65 years old, farmer)

Gandong history was read at traditional rituals in Baileo. The parents also always convey this to their children from generation to generation. Thus, all children and grandchildren from the land of gandong know it well from both the Christian and Muslim communities. Whenever and wherever they meet, they are always called onco (bongso). According to Ong (2013:14), oral culture has strong verbal cues and has a high human value, and represents the cultural identity of the Christian and Muslim communities. According to Kim (2007:241), cultural identity is part of the concept of an individual, which is based on his or her knowledge as a member of a social group accompanied by the values inherent in it. Jenkins (1996:18) stressed that identity refers to an individual or community that is distinguished by an individual or other communities.

Based on the history above, gandong swearing gives the meaning that it bound both the Christian and Muslim communities. They must take care of and protect each other from various threats of danger. They should help and assist each other to ease the tension between them. For example, if Hutumuri people carry out traditional inauguration rituals, the Christian Sirisori, the Islamic Sirisori and the Tamilou will provide resources in the form of food. However, if the Tamilou is about to rebuild the mosque, the three other countries will help see the work of the mosque to completion. Malatuny and Ritiauw (2018:38) emphasise that the existence of customary swear is absolutely necessary as a guide to the ability of a community (Christians and Muslims) in building their life that is always aligned with cultural values and traditional rules of a community to social order. Moreover, according to Hehanussa (2009:9-10) through customary swearing, Christian and Muslim communities live in mutual respect without dominating each other because 'I am part of you and you are part of me', or they acknowledge their differences. Thus, they create unity without involvement with other communities, and there is no self-identity found.

\section{Design stage: Reviving the solidarity of Christian and Muslim community brotherhood through the Baileo}

At the Design stage, the authors analysed data relating to the realisation of the best experiences and opportunities of both the discover and dream stages. After the social conflict in Maluku in 1999, the central and regional governments have made various efforts to reconcile the Christian and Muslim communities in Maluku. These efforts involve inviting 1500 representatives of leaders from both Christian and Muslim communities to Malino in order to discuss the resolving of social conflicts in Maluku; and returning refugees to their respective regions or countries, such as refugees in North Seram, Amahai and Waipia districts (Dandirwalu \& Rehy 2020:68). However, the efforts have not come to fruition as demonstrated by the social conflicts in 2011 and 2012 that took place in Ambon city, which has a psychological-social impact on other areas of Maluku. There are two causes. Firstly, the government still uses a universal approach. The government also 'seems' to homogenise the diversity and peculiarities of culture or customs of people in Maluku. For instance, the culture or customs in Kei region cannot be necessarily equated with those of the Central Maluku region. Secondly, a community's cultural or indigenous values are difficult to reveal through a 'formalistic' meeting because meetings related to the disclosure of cultural or community values are always sacred.

Reviving collective memory amongst Christian and Muslim communities in Maluku has become an important part of the peace process in Maluku. The collective memory represents the previous traditional values before the social conflict in 1999 in Maluku. It became the institution in the community in social interaction and religious community both Christian and Muslim. Related to the concept of collective memory, Noa and Yigal (1996) argue that collective memory is a less common term based on Jonathan Frankel's article entitled The Yizkor Book of 1911 - A Note on National Myths in the Second Aliyah. The article discusses collective memory, but the term is only mentioned twice. Firstly, it is combined with the word 'unconscious', and secondly, it is combined with the word 'conscious' (Noa \& Yigal 1996:30-31). Noa and Yigal (1996:32) do not contrast both terms. For them, both have the advantage that is a separation amongst fields, which are dominated by factors 'beyond human control'. According to Funkenstein (1989:6), there can be awareness and memory in individuals who are active, conscious and remember their activities. In other words, collective memory departs from humans based on their experiences. Then these experiences become part of the 'subconscious' and 'consciously' as their value.

The views of Noa and Yigal (1996) are in line with the concepts of Olick (1999). According to him, collective memory is always based on individualistic principles. 
It means that individual memories are collected from members of a community, so the centre of collective memory is the individual (Olick 1999:338). In contrast, Zerubavel's (1996) stance tends to accommodate both. He uses the term 'social memory', namely, a memory process that involves not only individual memory but also collective memory. The tendency that occurs is that social memory is part of collective memory, for example, America's collective memory of the Vietnam war, Israel's collective memory of the Holocaust (Zerubavel 1996:293-294).

During the interviews with the kings of Hutumuri, Christian Sirisori, Islamic Sirisori and Tamilou, they stated as follows:

'We are trying to re-established [sic] the relationship among brothers and sisters that existed before the social conflict in 1999 in Maluku.' (King of Tamilou, 57 years old, retired state civil servant)

'... so that we can meet together again.' (King of Hutumuri, 52 years old, private)

'We re-perform the traditional rituals together in Baileo.' (King of Islamic Sirisori, 59 years old, self-employed)

'... to get the bonds of brotherhood among us back to our lives'. (King of Christian Sirisori, 65 years old, farmer)

The opinion of traditional leaders from Hutumuri, Christian Sirisori, Islamic Sirisori is in line with that of the kings, which is expressed as follows:

'The current longing is the ties gandong can [sic] re-established very harmonious and peaceful life as before.' (Traditional leader from Islamic Sirisori, 68 years old, farmer)

'We believe we can re-establish the bonds of gandong that were destroyed during the social conflict in 1999 in Maluku ...' (Traditional leader from Christian Sirisori, 65 years old, farmer)

'... so that we can carry out the traditional rituals in Baileo together.' (Traditional leader from Hutumuri, 68 years old, farmer)

'... so far, we do it individually in each country'. (Traditional leader from Islamic Tamilou, 69 years old, farmer)

Furthermore, based on the interviews with Christian and Muslim religious leaders from Hutumuri, Christian Sirisori, Islamic Sirisori and Tamilou, the authors received the following information:

'We as religious leaders, in principle, are sibling countries.' (Religious leader from Islamic Sirisori, 61 years old, ulama)

'Hutumuri, Christian Sirisori, Sirisori Islam, and Tamilou can reconcile so that the lives of the brotherhood can be re-created as before.' (Religious leader from Christian Sirisori, 45 years old, pastor)

'Therefore, as religious leaders from the Christian and Muslim communities, we continue to assist kings and traditional leaders to revive the values of the brotherhood without religious differences ...' (Religious leader from Hutumuri, 51 years old, pastor)

'... through communication and involvement in all traditional rituals carried out in Baileo by those gandong countries namely Hutumuri, Sirisori Christian, Islamic Sirisori, and Tamilou.' (Religious leader from Tamilou, 63 years old, ulama)
Based on the interviews with community leaders from Hutumuri, Christian Sirisori, Islamic Sirisori, and Tamilou, the authors obtained the following information:

'We miss the atmosphere before the 1999 social conflict in Maluku ...' (Community leader from Hutumuri, 58 years old, state civil servant)

'... because we can meet each other ...' (Community leader from Tamilou, 59 years old, farmer)

'... either through traditional rituals in Baileo or social interactions.' (Community leader from Christian Sirisori, 59 years old, farmer)

'We are working on it so that we can re-create a harmonious life.' (Community leader from Islamic Sirisori, 61 years old, farmer)

Based on the above interview, it is illustrated that the Christian and Muslim communities have a collective memory of the past before the 1999 social conflict in Maluku, namely, reviving the solidarity of the brotherhood of Christian and Muslim communities through Baileo. The construction of collective memory is based on several factors.

The first is consciousness. Both Christian and Muslim communities have the consciousness that they are the victims of the 1999 social conflict in Maluku, or in other words, the breakdown of gandong ties. The consciousness is important because the issue that appeared during the conflict is a religious conflict. According to Jati (2013) religion cannot be used as an issue of conflict in Maluku because it is only used as prejudice or support. The root of the conflict is the struggle for economic and political resources, and bureaucracy (Jati 2013:394). Dimah (2009) who discussed Sikod's thoughts, stated that the cause of social conflict in Africa is the failure of the African government to implement policies fairly and effectively related to the availability of food for the community, so that civil conflict often occurs in Africa. He identified several conflicts that occur in Africa, namely, conflict of liberation that occurred in Angola and Western Sahara, religious conflicts in Algeria, border conflicts between Ethiopia-Eritrea and Cameroon-Nigeria, ideological conflicts in Angola and Mozambique, and peasants' conflicts in Northwest Cameroon (Dimah 2009:132-133). Meanwhile, according to Osei-Kyei et al., the causes of the conflicts that are reported in Ghana and China were related to bad governance and the arrangement of work contracts between the public and the private sector (Osei-Kyei et al. 2018:1). Naumkin (2019) who researched in Russia, found that the cause of the conflict in Russia was ethnopolitics, which directly affected Russia. Suyanto (2007) researched conflicts that occurred in Jambi and West Sumatra, where the cause of the conflict was the ongoing tenurial conflict between oil palm plantations and farmers because the company did not provide compensation to them (Suyanto 2007:68). According to Sangadji (2014), the conflict in the 20th century was a conflict among countries. However, between 1989 and 1996, inter-ethnic conflicts often occurred, such as in 1991 between Serbia and Bosnia, and tribal wars between Hutu and Tutsi, which occurred in 1994 with the cause was wanting to emphasise recognition of communal identity (Sangadji 2014). 
The second is cultural romanticism. Both Christian and Muslim communities have positive memories that originate from various experiences in a culture that have bound them in relationships without being restricted by religious and ethnic differences, such as pela, gandong, masohi, maren and aini ain. This cultural romanticism is an encouragement or strength for them to create a sentiment to live together as siblings in Maluku without any religious and ethnic differences. Holbrook (1997:105) argues that cultural romanticism is an important part of individuals because essentially cultural romanticism has a spiritual value that appears all the time. According to Handler (1989:1), cultural romanticism is an aesthetic revolution in which selfexpression, creativity, sincerity and spontaneity are part of every individual. Van Klinken (2014:2) sees romanticism as historical truth. It means that civilisation is always rooted in the past, there is no future without the past, and humans can build a future after learning from the past.

The third is imaging. This factor is closely related to the activities that take place in Baileo, such as traditional rituals and deliberation in solving various problems. Through this activity, narratives relating to the history of encounters, traditional promises and customary prohibitions are conveyed. Thus, they indirectly re-form the 'subconscious' mind of the Christian and Muslim communities so that fraternal solidarity between the two communities became increasingly stronger, confirmed by Larson (1984:26) as words of faith. Based on a note from the editor of the book Carita Orang Basudara, the storytelling tradition has become a habit of Maluku people. Each mother tells stories to her children as an introduction before bed such, as the story of a fairy tale and life experiences (Manuputty et al. 2014:v). Ong (2013:6-7), in Orality and Literacy, explained that storytelling is part of spoken language and that humans communicate with each other with various models, take advantage of the senses, touch, taste, and are articulated through sound.

The researchers argue that the presence of the collective memory will not eliminate the individual memory because of two factors. Firstly, the individual memory also constructs the collective memory of a community. When talking about collective memory, it is also talking about individual memory. Secondly, the dynamics of individual memory greatly impact the dynamics of community collective memory.

\section{Destiny stage: Implementation of the traditional ritual of the inauguration of the King of Hutumuri in Baileo as an embodiment of peace for the Christian and Muslim communities in Maluku}

At this stage, the authors analysed data related to efforts to create a social order that allows the involvement of all parties for a change. Thus, the implementation of the ritual custom of the inauguration of the king of Hutumuti country in Baileo on Friday, 20 March 2020, is a manifestation of the peace amongst Christian and Muslim communities in Maluku. The countries that took part include Christian Sirisori, Islamic Sirisori and Tamilou (Islam). The four countries involved Christian and Muslim communities.

Based on the results of interviews with the kings of Hutumuri, Christian Sirisori, Islamic Sirisori and Tamilou, they stated that:

'The inauguration ceremony of the King of Hutumuri Country

...' (King of Tamilou, 57 years old, retired state civil servant)

'... is a starting point for re-knitting the bonds of brotherhood among us ...' (King of Hutumuri, 52 years old, private)

'... because all countries that are members of the ties gandong may attend.' (King of Christian Sirisori, 53 years old, self-employed)

'Those are Christian Sirisori, Islamic Sirisori, and Tamilou.' (King of Islamic Sirisori, 59 years old, self-employed)

Traditional figures from Hutumuri, Christian Sirisori, Islamic Sirisori and Tamilou have the same opinion as the kings:

'As traditional leaders, we are very happy ...' (Traditional leaders from Tamilou [69 years old, farmer], Islamic Sirisori [68 years old, farmer] and Christian Sirisori [65 years old, farmer])

'... because all sibling countries including Sirisori and Tamilou which are Islam can attend the traditional rituals of the inauguration ofnthe king in Baileo'. (Traditional leader from Hutumuri, 68 years old, farmer)

Furthermore, based on interviews with Christian and Muslim religious leaders from the Hutumuri, Christian Sirisori, Islamic Sirisori and Tamilou, the authors obtained the following information:

'We are grateful to Allah.' (Religious leader from Hutumuri, 51 years old, pastor)

'[F]inally, the Christian and Muslim communities can reunite at the inauguration of the king of Hutumuri.' (Religious leaders from Tamilou [63 years old, ulama], Islamic Sirisori [61 years old, ulama] and Christian Sirisori [45 years old, pastor])

Then, based on interviews with community leaders from Hutumuri, Christian Sirisori, Islamic Sirisori and Tamilou, the authors obtained the following information:

'We are very happy because we can meet our brothers who are different religions of the Hutumuri community.' (Community leaders from Hutumuri [58 years old, state civil servant], Christian Sirisori [59 years old, farmer], Islamic Sirisori, [61 years old, farmer] and Tamilou [59 years old, farmer])

Based on the interview data above, through the traditional ritual of the inauguration of the king of Hutumuri which took place in Baileo, they realise peace. This peace is based on mutual trust among them. Without mutual trust, it is difficult to achieve peace between Christian and Muslim communities in Maluku. It is a sign that the gandong bonds between Christian and Muslim communities are still part of their institutions. Held (1986:157) states that the important value of trust is when we do not know whether someone will or will not do something to us. It is clear that when the Muslim community is present and lives in the Christian community, they never think that they were attacked or killed. 
Giddens (1990:83), meanwhile, discusses beliefs in two forms: firstly, trust between individuals or communities who know each other, and secondly, beliefs in abstract systems, where there is no meeting with the individual or community responsible for them. The authors prefer the first form because the beliefs created among the Christian and Muslim communities are based on the bonds of brotherhood, namely, gandong, as Seligman's concept that 'basic beliefs' are placed on beliefs personified in the community, namely, kinship and friendship (Seligman 1997:17).

Another reason the authors favour Giddens' first form of beliefs is because there is equality between the Christian and Muslim communities in Maluku. It does not eliminate the differences between them or impose their beliefs on each other. Therefore, Beaman (2017:85) uses the term 'you are Christian, I am Sikh, but it doesn't matter'. According to her, 'deep equality' is not based on interfaith dialogue but the experience of encounters between 'me' and 'him' (Beaman 2017:85). The experience of such encounters is based on the value of love, or according to Ferreira (1997:65), as a work of love containing the resources to understand the existence of the different reality. At this point, religion becomes very functional and contextual because it is not outside of the daily reality of the community. According to Hehanussa (2009) religious leaders have conveyed the value of love or the work of love to their followers (church or congregation), through words such as: 'all that you want others to do for you, then do it also for others', 'love your neighbour as yourself', 'who can keep his tongue and hands from hurting others' and the expression, 'Assalamu' alaikum. 'Assalamu'alaikum means greeting to you. It has important values in Islam, namely, the meaning of love, compassion and peace. Its meaning is based on the words of the Prophet Muhamad: 'spread greetings to people you know and do not know' (Zulkifli 2016:190) and 'Metta/Maitri, Karuna teachings' (Zulkifli 2016:191-193), as taught in Zoroaster teachings in the eighth century BC, Buddhism and Confucius 500 years BC, Jesus' teachings from the first century, and Islamic teachings in the ninth century (Hehanussa 2009:10).

\section{Conclusion}

The culture or customs of a community has an important value for the creation of peace amongst different religions: Christianity, Catholicism, Islam, Hinduism, Buddhism and Confucianism. The culture or customs of Baileo in Maluku present it. Baileo becomes a symbol and model of peace in the resolution of socio-religious conflict that occurs in Maluku. Why? Because the culture or customs of a community have theological values that can be used as universal values of all religions, that is, equality amongst human beings. The equality means love, compassion, peace and salvation amongst human beings.

As a result of the 1999 social conflict in Maluku, several countries in Central Maluku Regency with gandong ties have lost traditional rituals in Baileo as previously involves Christian and Muslim communities. These countries include Hutumuri (Christian), Sirisori (Christian),
Sirisori (Islam) and Tamilouw (Islam). After the conflict, all parties made great efforts to re-create peace in these countries. Unfortunately, it has not come to fruition yet, as shown by the conflicts in 2004 and 2011 in Maluku.

Baileo is a model of peace for Christian and Muslim communities of those countries in Maluku. It has four meanings. Firstly, Baileo as a place to create solidarity between Christian and Muslim communities. The gandong bond between them before the social conflict created solidarity. Baileo worked well because of the regularity and involvement in all social and traditional activities. Secondly, local traditions in the form of Baileo and gandong became the meeting point of Christian and Muslim communities because it has a sacred value, and they interpret gandong as mutually guarding and protecting as a form of implementation of the promises made by their ancestors. Thirdly, it revives the solidarity of the Christian and Muslim community fraternities. After the social conflict in 1999 in Maluku, both have the collective memory of shared values. It is based on the existence of mutual consciousness, cultural romanticism and re-storytelling. Fourthly, there is implementation of the traditional ritual of the inauguration of Hutumuri King in Baileo as the embodiment of the peace of the Christian and Muslim communities in Maluku. This embodiment can take place well to the recent day because of the absence of mutual suspicion between them and the existence of equality between the two religions, namely, Christianity and Islam.

\section{Acknowledgements Competing interests}

The authors declare that they have no financial or personal relationships that may have inappropriately influenced them in writing this article.

\section{Authors' contributions}

R.D. and H.Q. contributed equally to this research article.

\section{Ethical considerations}

This article followed all ethical standards for research without direct contact with human or animal subjects.

\section{Funding information}

This research study received no specific grant from any funding agency in the public, commercial or not-for-profit sectors.

\section{Data availability}

Data sharing is not applicable to this article as no new data were created or analysed in this study.

\section{Disclaimer}

This views and opinions expressed in this article are those of the authors and do not necessarily reflect the official policy or position of any affiliated agency of the authors. 


\section{References}

Abidin, Z., 2014, 'Teologi Inklusif Nurcholish Madjid: Harmonisasi Antara Keislaman, Keindonesiaan, dan Kemoderenan', Humaniora 5(2), 682. https://doi. org/10.21512/humaniora.v5i2.3123

Alfaqi, M.Z., 2015, 'Memahami Indonesia Melalui Prespektif Nasionalisme, Politik Identitas, Serta Solidaritas Mifdal Zusron Alfaqi', Jurnal Pendidikan Pancasila Dan Kewarganegaraan 28(2), 111-116.

Amir, S., 2013, 'Pancasila as integration philosophy of education and national character', International Journal of Scientific and Technology Research 2(1), 54-57.

Asadu, G.C., Diara, B.C. \& Asogwa, N., 2020, 'Religious pluralism and its implications for church development', HTS Teologiese Studies/Theological Studies 76(3), 1-9. https://doi.org/10.4102/hts.v76i3.5955

Bakri, H., 2015, 'Resolusi Konflik melalui Pendekatan Kearifan Lokal Pela Gandong di Kota Ambon', The POLITICS: Jurnal Magister IImu Politik Universitas Hasanuddin $1(1), 51-60$

Banawiratma, J.B., 1988, 'Teologi Fungsional-Teologi Kontekstual', in E. Darmaputra (ed.), Konteks Berteologi Di Indonesia, 1st edn., pp. 51-53, BPK Gunung Mulia, Jakarta.

Beaman, L.G., 2017, Deep equality in an era of religious diversity, 1st edn., Oxford University Press, New York, NY.

Bell, C., 1992, Ritual theory, ritual practice, Oxford University Press, New York, NY.

Bevans, S.B., 2002, Model-Model Teologi Kontekstual, Ledalero, Maumere.

Bielo, J.S., 2018, 'Anthropology, theology, critique', Critical Research on Religion 6(1), 28-34. https://doi.org/10.1177/2050303218757323

Birx, H.J., 2006, Encyclopedia of anthropology, vol. 12, SAGE, Thousand Oaks, CA.

Carter, M.J. \& Fuller, C., 2016, 'Symbols, meaning, and action: The past, present, and future of symbolic interactionism', Current Sociology 64(6), 931-961. https://doi. org/10.1177/0011392116638396

Casram, C., 2016, 'Membangun Sikap Toleransi Beragama dalam Masyarakat Plural', Wawasan: Jurnal Ilmiah Agama Dan Sosial Budaya 1(2), 193. https://doi. org/10.15575/jw.v1i2.588

Cassirer, E., 1944, An essay on man, Yale University Press, New Haven, CT.

Cooley, F.L., 1987, Mimbar dan Takhta, Pustaka Sinar Harapan, Jakarta.

Cooperrider, D.L., Whitney, D. \& Stavros, J.M., 2005, Appreciative inquiry handbook, Berrett-Koehler, Oakland, CA.

Creswell, J.W. \& Creswell, D., 2018, 'Research design qualitative, quantitative, and mixed methods approaches', in Journal of Chemical Information and Modeling, 5 th edn., vol. 53, Sage, Los Angeles, CA.

Dandirwalu, R., 2014, 'Totem Ambon Manise: Membongkar Segregasi Teritorial Berbasis Agama di Kota Ambon', Antropologi Indonesia 35(1), 30-44.

Dandirwalu, R. \& Rehy, H.Y., 2020, 'Tahuri: Symbol of the Christian-Muslim community peace in Tehoru and Telutih, Central Maluku, Indonesia', Wawasan: community peace in Tehoru and Telutih, Central Maluku, Indonesia', Wawasan:
Jurnal Ilmiah Agama Dan Sosial Budaya 5(1), 67-76. https://doi.org/10.15575/ Jurnal Ilmiah

Dean, J., 1995, 'Reflective solidarity', Constellations 2(1), 115. https://doi.org/10.1111/ j.1467-8675.1995.tb00023.x

Dimah, A., 2009, 'The roots of African conflicts: The causes and costs', Africa Today 55(4), 132-133. https://doi.org/10.1177/001316447503500129

Durkheim, E., 1915, The elementary forms of the religious life, The Free Press, New York, NY

Eliade, M., 1957, The sacred and the profane: The nature of religion, Rowohlt Taschenbuch Verlang $\mathrm{GmbH}$, New York, NY.

Eliade, M., 1985, Symbolism: The sacred, and the arts, The Crossroad, New York, NY.

Eriksen, T.H., 2017, What is anthropology?, Pluto Press, London.

Faisal, F., Mulkhan, A.M., Nurmandi, A. \& Jubba, H., 2019, 'From conflict to assimilation: Strategies of Muslim immigrants in Papua special autonomy era', Wawasan: Jurnal Ilmiah Agama Dan Sosial Budaya 4(1), 103-116. https://doi. org/10.15575/jw.v4i1.5190

Ferreira, M.J., 1997, 'Equality, impartiality, and moral blindness in Kierkegaard's works of love', Journal of Religious Ethics 25(1), 65. https://doi.org/10.1515/ 9783110803044.206

Funkenstein, A., 1989, 'Collective memory and historical consciousness', History and Memory 1(1), 6

Giddens, A., 1990, 'The consequences of modernity, Farbe und Lack, vol. 103, Polity Press in Association with Blackwell Publishers Ltd., Stanfoard, CA.

Handler, R., 1989, 'Anti-romantic romanticism: Edward Sapir and the critique of American individualism', Anthropological Quarterly 62(1), 1. https://doi. org $/ 10.2307 / 3317902$

Hehanussa, J., 2009, 'Pela dan Gandong: Sebuah Model untuk Kehidupan Bersama dalam Konteks Pluralisme Agama di Maluku', Gema Teologika 33(1), 1-15.

Held, V., 1986, 'On the meaning of trust', Ethics 78(2), 156-159.

Holbrook, M.B., 1997, 'Romanticism, introspection, and the roots of experiential consumption: Morris the Epicurean', Consumption Markets \& Culture 1(2), 105 https://doi.org/10.1080/10253866.1997.9670295
Iwamony, R., 2019, 'From exclusivism to pluralism: Shifting perspective of the Gereja Protestan Maluku (GPM) in interreligious relations' Wawasan: Jurnal IImiah Agama Dan Sosial Budaya 4(2), 117-131. https://doi.org/10.15575/ jw.v4i2.4829

Jati, W.R., 2013, 'Kearifan Lokal sebagai Resolusi Konflik Keagamaan', Walisongo: Jurnal Penelitian Sosial Keagamaan 21(2), 393-416. https://doi.org/10.21580/ ws.2013.21.2.251

Jenknis, R., 1996, Social identity, 1st edn., Routledge, Taylor and Francis Group, London and New York, NY.

Kim, Y.Y., 2007, 'Ideology, identity, and intercultural communication: An analysis of differing academic conceptions of cultural identity', Journal of Intercultural Communication Research 36(3), 237-253. https://doi.org/10.1080/17475 750701737181

Kluckhohn, C., 1985, Antropología, Fondo De Cultura Economica, Mexico, MX.

Kottak, C.P., 2015, Cultural anthropology: Appreciating cultural diversity, McGraw-Hill Education, New York, NY.

Larson, J., 1984, 'Stories sacred and profane: Narrative in one flew over the cuckoo's nest', Religion and Literature 16(2), 26.

LeRon Shults, F., 2010, 'God and the world of signs: Semiotics and theology', Zygon 45(3), 713-732. https://doi.org/10.1163/ej.9789004187993.i-382

Lestari, D.T., 2020, 'Merawat Harmoni Agama melalui Kolaborasi Musik Hadroh dan Trompet di Ambon', Religious: Jurnal Studi Agama-Agama Dan Lintas Budaya 4(3), 215-226. https://doi.org/10.15575/rjsalb.v4i3.8880

Malatuny, Y.G. \& Ritiauw, S.P., 2018, 'Eksistensi Pela Gandong Sebagai Civic Culture', Sosio Didaktika: Social Science Education Journal 5(2), 35-46.

Manuputty, J., Zalampessy, Z., Ali-Fauzi, I. \& Rafsadi, I., 2014, 'Carita Orang Basudara. Kumpulan Kisah-Kisah Perdamaian dari Maluku', in J. Manuputty, Z. Zalampessy., I. Ali-Fauzi \& I. Rafsadi (eds.), Carita Orang Basudara. Kumpulan Kisah-Kisah Perdamaian dari Maluku (Pertama), pp. 1-404, Lembaga Antar Iman Maluku, Pusat Studi Agama-Agama dan Demokrasi, Yayasan Paramadina, Jakarta.

Min Kim, S., Banawiratma, J.B. \& Sofjan, D., 2020, 'Religious pluralism discourse in public sphere of Indonesia: A critical application of communicative action theory to inter-religious dialogue', Religió: Jurnal Studi Agama-Agama 10(2), 158-188. https://doi.org/10.15642/religio.v10i2.1307

Moody, H.R. \& Achenbaum, W.A., 2014, 'Solidarity, sustainability, stewardship: Ethics across generations', Interpretation 68(2), 152. https://doi.org/10.1177/ 0020964313517656

Morris, B., 2003, Antropologi Agama, AK Group, Yogyakarta.

Musurillo, H., 1957, 'History and symbol: A study of form in early Christian literature', Theological Studies 18(3), 357. https://doi.org/10.1177/004056395 literature',
701800302

Naumkin, V.V., 2019, 'Causes of ethno-political conflicts and approaches to their resolution', Herald of the Russian Academy of Sciences 89(2), 125. https://doi. org/10.1134/S101933161902014X

Noa, G. \& Yigal, E., 1996, 'Collective memory - What is it?', History and Memory 8(1), 30-50.

Normuslim, N., 2018, 'Kerukunan Antar Umat BeragamaKeluarga Suku Dayak Ngaju di Palangka Raya', Wawasan: Jurnal IImiah Agama Dan Sosial Budaya 3(1), 66-89. https://doi.org/10.15575/jw.v3i1.1268

Olick, J.K., 1999, 'Collective memory: The two cultures', Sociological Theory 17(3), 338. https://doi.org/10.1111/0735-2751.00083

Ong, J.W., 2013, Orality and literacy, 30th anniversary edn., Routledge, New York, NY.

Oppenshaw, D.L., Nel, M. \& Louw, L., 2018, 'Conflict resolution and reconciliation within congregations', HTS Teologiese Studies/Theological Studies 74(1), 37-42. within congregations', HTS Teologiese Stud
https://doi.org/10.4102/hts.v74i2.4641

Osei-Kyei, R., Chan, A.P.C., Yu, Y., Chen, C. \& Dansoh, A., 2018, 'Root causes of conflict and conflict resolution mechanisms in public-private partnerships: Comparative study between Ghana and China', Cities 87, 185-195. https://doi.org/10.1016/j. study between Ghan
cities.2018.10.001

Parihala, Y. \& Busro, B., 2020, 'Reclaiming Jesus as source of peace in Luke 12:49-53 through the perspective of religious pluralism in an Indonesian context', HTS Teologiese Studies/Theological Studies 76(4), a6088. https://doi.org/10.4102/hts. veologiese

Pattipeilohy, S.Y.E., 2018, 'Ketuhanan yang BerkebudayaanKetuhanan yang Berkebudayaan: Memahami Pancasila sebagai Model Interkulturalitas', Gema Teologika 3(2), 121. https://doi.org/10.21460/gema.2018.32.363

Rejeki Waluyajati, R.S. \& Farida, L.U., 2018, 'Pola Interaksi Sosial Keagamaan Antara Penganut Agama Islam Dan Kristen Advent (Studi Kasus di Desa Cihanjuang Rahayu Kecamatan Parongpong Kabupaten Bandung Barat)', Religious: Jurnal Studi Agama-Agama Dan Lintas Budaya 2(2), 85. https://doi.org/10.15575/rjsalb. v2i2.3097

Robert, Y.K., 2011, Qualitative research from start to finish, The Guilford Press, New York, NY.

Roswantoro, A., 2016, 'Resolusi Konflik dalam Masyarakat Religius Indonesia', Religio: Jurnal Studi Agama-Agama 8(2), 187. https://doi.org/10.15642/religio.v8i2.785

Sangadji, A.Z., 2014, 'Tragedi Di Simpang Transisi', in J. Manuputty, Z. Salampessy, I. Ali-Fauzi \& I. Rafsadi (eds.), Carita Orang Basudara, Kumpulan Kisah-Kisah Perdamaian dari Maluku (pertama), Lembaga Antar Iman Maluku, Pusat Stud Agama-Agama dan Demokrasi, Yayasan Paramadina, Jakarta.

Schreiter, R.J., 1985, Constructing local theology, SCM Press Ltd., London. 
Segal, R.A., 1997, 'The myth and ritual theory: An anthology', The Journal Jewish Thought and Philosophy 6(2), 1-18. https://doi.org/10.2307/2660735

Seligman, A.B., 1997, 'The problem of trust', Social Forces 77(4), 1693-1694. https:// doi.org/10.2307/3005928

Singgih, E.G., 2016, Dari Israel Ke Asia, 2nd edn., BPK Gunung Mulia, Jakarta.

Suparlan, P., 2014, 'Keyakinan Keagamaan dalam Konflik antarsukubangsa', Antropologi Indonesia 0(66), 23-33. https://doi.org/10.7454/ai.v0i66.3420

Suyanto, S., 2007, 'Underlying cause of fire: Different form of land tenure conflicts in Sumatra', Mitig Adapt Strat Glob Change 12, 67-74. https://doi.org/10.1007/ s11027-006-9039-4

Tarekegn, L.N. \& Terefe, M.F., 2019, 'Hebo: New year ritual of Yem people in South West Ethiopia', International Journal of Multicultural and Multireligious Understanding 6(4), 591. https://doi.org/10.18415/ijmmu.v6i4.1207
Van Klinken, G., 2014, 'Ale Rasa Beta Rasa. Menyusun Sejarah Bersama di Ambon', in J. Manuputty, Z. Salampessy, I. Ali-Fauzi \& I. Rafsady (eds.), Carita Orang Basudara. Kumpulan Kisah-Kisah Perdamaian dari Maluku (Pertama), pp. 1-11, Lembaga Antar Iman Maluku, Pusat Studi Agama-Agama dan Demokrasi, Yayasan Paramadina, Jakarta.

Waltkins, J.M., Mohr, B. \& Kelly, R., 2011, Appreciative inquiry: Change at the speed of imangination, 2nd edn., Pfeiffer, San Francisco, CA.

Whitney, D. \& Trosten-Bloom, A., 2014, 'The power of appreciative inquiry: A practical guide to positive change, Performance Improvement 53(8), 47. https://doi. org/10.1002/pfi.21433

Zerubavel, E., 1996, 'Social memories: Steps to a sociology of the past', Qualitative Sociology 19(3), 293-294. https://doi.org/10.1007/bf02393273

Zulkifli, Z., 2016, 'Doktrin Kasih Dalam Tradisi Agama-Agama Besar: Antara Teori Dan Praktik', IImu Ushuluddin 3(2), 191-193. 